\title{
British Imperialism in the Nineteenth Century
}

Each volume in the 'Problems in Focus' series is designed to make available to students important new work on key historical problems and periods that they encounter in their courses. Each volume is devoted to a central topic or theme, and the most important aspects of this are dealt with by specially commissioned studies from scholars in the relevant field. The editorial Introduction reviews the problem or period as a whole, and each chapter provides an assessment of the particular aspect, pointing out the areas of development and controversy, and indicating where conclusions can be drawn or where further work is necessary. An annotated bibliography serves as a guide to further reading. 


\section{PROBLEMS IN FOCUS SERIES}

\section{TITLES IN PRINT}

Church and Society in England: Henry VIII to James I edited by Felicity Heal and Rosemary O'Day

The Reign of James VI and I

edited by Alan G. R. Smith

The Origins of the English Civil War

edited by Conrad Russell

The Interregnum: The Quest for Settlement 1646-1660

edited by G. E. Aylmer

The Restored Monarchy 1660-1688

edited by J. R. Jones

Britain after the Glorious Revolution 1689-1714

edited by Geoffrey Holmes

Popular Movements, c. 1830-1850

edited by J. T. Ward

Europe's Balance of Power 1815-1848

edited by Alan Sked

The Edwardian Age: Conflict and Stability 1900-1914

edited by Alan O'Day

The Mid-Tudor Polity c. 1540-1560

edited by Jennifer Loach and Robert Tittler

Slavery and British Society 1776-1846

edited by James Walvin

Reactions to the English Civil War 1642-1649

edited by John Morrill

Britain in the Age of Walpole

edited by Jeremy Black

The Reign of Elizabeth I

edited by Christopher Haigh

British Imperialism in the Nineteenth Century

edited by C. C. Eldridge

The Revolution in Ireland, 1879-1923

edited by D. G. Boyce

Later Victorian Britain, 1867-1900

edited by T. R. Gourvish and Alan O'Day 


\section{British Imperialism in the Nineteenth Century}

EDITED BY

C. C. ELDRIDGE

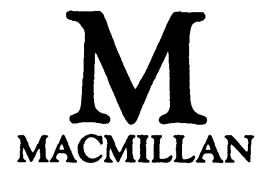


(c) A. E. Atmore, Christine Bolt, Peter Burroughs, M. E. Chamberlain, C. C. Eldridge, Paul Kennedy, R. J. Moore, James Sturgis 1984

All rights reserved. No reproduction, copy or transmission of this publication may be made without written permission.

No paragraph of this publication may be reproduced, copied or transmitted save with written permission or in accordance with the provisions of the Copyright Act 1956 (as amended), or under the terms of any licence permitting limited copying issued by the Copyright Licensing Agency, 33-4 Alfred Place, London WC1E 7DP.

Any person who does any unauthorised act in relation to this publication may be liable to criminal prosecution and civil claims for damages.

First published 1984

Reprinted 1987, 1989

Published by

MACMILLAN EDUCATION LTD

Houndmills, Basingstoke, Hampshire RG21 2XS

and London

Companies and representatives

throughout the world

British Library Cataloguing in Publication Data

Eldridge, C. C.

British imperialism in the 19th century.-(Problems in focus)

1. Imperialism 2. Great Britain-

Foreign relations-1837-1901

I. Title II. Series

321'.03'0941 JV1016

ISBN 978-0-333-26909-1 ISBN 978-1-349-17655-7 (eBook)

DOI 10.1007/978-1-349-17655-7 


\section{Contents}

List of Maps vi

List of Abbreviations vi

Acknowledgements vii

Introduction $\quad$ c. C. ELDRIDGE 3

1 Continuity and Discontinuity in British
Imperialism 1815-1914

PAUL KENNEDY

2 Colonial Self-government 39 PETER BURROUGHS

3 India and the British Empire 65

R. J. MOORE

4 Britain and the New Imperialism 85 JAMES STURGIS

5 The Extra-European Foundations of British Imperialism: Towards a Reassessment $\quad 106$ A. E. ATMORE

6 Race and the Victorians 126 CHRISTINE BOLT

7 Imperialism and Social Reform 148 M. E. CHAMBERLAIN

8 Sinews of Empire: Changing Perspectives 168 c. C. ELDRIDGE

Notes and References 190

Suggestions for Further Reading 201

Notes on Contributors 207

Index 208 


\section{List of Maps}

1 India on the eve of the Indian Mutiny 64

2 Africa: the final stage of partition, $1914 \quad 92$

\section{List of Abbreviations}

CHBE Cambridge History of the British Empire

CHR Canadian Historical Review

EHR English Historical Review

EconHR Economic History Review

HJ Historical Journal

$J A H \quad$ Journal of African History

JEH Journal of Economic History

JICH Journal of Imperial and Commonwealth History

$P E P \quad$ Past and Present 


\section{Acknowledgements}

The editor gratefully acknowledges financial assistance received from the Pantyfedwen Fund of Saint David's University College for the preparation of the manuscript for publication. He also wishes to thank Sarah Mahaffy, Vanessa Peerless and Judy Marshall of Macmillan for their constant encouragement, help and advice during the production of the volume.

The editor and publisher wish to thank Hodder \& Stoughton Educational for permission to reproduce the map on p. 64, depicting India on the eve of the Indian mutiny. This was originally published in Victorian Imperialism by C. C. Eldridge, The map on p. 127, Africa in 1914, is reproduced with the permission of Cambridge University Press, and first appeared in Africa Since 1800 by R. Oliver and A. Atmore. 